Revista Iberoamericana, Vol. LXXX, Núm. 247, Abril-Junio 2014, 611-630

\title{
2666, O LA LEGITIMIDAD DE LA LITERATURA EN TIEMPOS "POST"
}

\author{
POR \\ ILSE LOGIE \\ Universidad de Gante
}

\section{El Apocalipsis Según Bolaño}

En toda su obra, Roberto Bolaño (1953-2003) ha explorado a fondo el tema del mal. Ocupa una posición central en las novelas La literatura nazi en América, Estrella distante y Nocturno de Chile, para reaparecer en su ambicioso fresco póstumo 2666. Lo que Bolaño suele llamar el 'mal absoluto' se generalizó en la totalidad del siglo xx para empezar a contagiar ya el siglo xxı y abatirse sobre la condición humana de todo el planeta.

Por varios motivos, 2666 se inscribe en la tradición apocalíptica ${ }^{1}$ que el propio autor consideraba, junto con la aventurera, la única que permanece viva en Latinoamérica (Entre paréntesis 215). Desde el punto de vista temático, la novela recorre los mataderos de Europa que cubren casi un siglo entero para terminar en el presente siniestro de una ciudad mexicana limítrofe con Estados Unidos, Santa Teresa (trasunto ficticio de Ciudad Juárez), donde desde 1993 se han cometido centenares de inexplicables asesinatos de mujeres. Por otra parte, 2666 constituye una reescritura innegable del texto fundador del género bíblico, la Revelación de Juan de Patmos, con el que mantiene una relación intertextual demostrable. Aparte del título que, mediante la cifra 666, remite a la Bestia o al Anticristo, la novela activa todo un imaginario visionario que proviene de numerosas interpretaciones, realizadas en diferentes lugares y momentos de la historia occidental, y que son posteriores al surgimiento de este género, pero sin llegar a alcanzar el estatuto de auténticas citas. ${ }^{2}$

1 Es de consulta obligada al respecto el artículo de Paz Soldán (2008), donde se compara la estrategia fantástica de Cortázar en 'Apocalipsis de Solentiname' con la poética a fin de cuentas 'realista' (aunque no se trata de un realismo convencional) de Bolaño.

2 En 2666, se construyen redes intertextuales eruditas que casi nunca se explicitan y que otorgan prioridad a la tradición modernista sobre la bíblica. Así, Adam Kirsch (2008) ha identificado la importancia para la novela, y más especificamente para la escena de la conversación telefónica entre el periodista Sergio 
Sin embargo, la lectura que Bolaño nos ofrece del Apocalipsis se ha desviado considerablemente de la que inspira la fuente original. Si bien ha echado mano de elementos del léxico de la matriz bíblica (a través del uso reconocible de ciertos motivos apocalípticos muchas veces descontextualizados como los jinetes, la Bestia o la ciudad como valle de la muerte), ha desarticulado radicalmente su sintaxis, ya que faltan, a nivel macroestructural, un génesis o comienzo diegético identificable y un claro cierre, a la vez que predomina una realidad fragmentada y caótica. Según la tipología que hemos esbozado en el epílogo de nuestro libro Imaginarios apocalípticos (Fabry, Logie \& Decock 453-458), y que se concibe como escala gradual, 2666, por la desvinculación de las dos dimensiones de léxico y sintaxis, entraría en la categoría de la "refiguración mítica implícita”.

Cabe sostener no obstante que, simultáneamente, y con argumentos aún más sólidos, ejemplifica la modalidad "postapocalíptica” (Fabry, Logie \& Decock 453458), término con el que hemos designado un corpus de textos contemporáneos que presentan una versión mutilada del modelo de San Juan. En estos textos, se conserva el mitema de la catástrofe de gran magnitud, pero la perturbación que se ha producido en una sociedad determinada no queda contrarrestada por ninguna revelación radical: ${ }^{3}$ lejos de dar lugar a grandes proyectos utópicos, el colapso de la civilización revela en primer lugar las aporías del modelo de la (post)modernidad en su implacable versión neoliberal. Se intenta, sobre todo, captar una sensación que domina cada vez más en nuestra sociedad globalizada: la sensación de que el fin del mundo ya ha ocurrido. Se evoca un ambiente de destrucción acabada, asumida y muchas veces irreparable frente al cual se abren pocas vías de resistencia. ${ }^{4}$

2666 es, sin lugar a dudas, una novela emblemática al respecto. Domina en ella un estado postcatástrofe, que a su vez trae consigo un ambiente turbio e insoslayable que afecta a toda una comunidad. Es llamativa la medida en la que la dicotomía civilización/ barbarie, tan fundamental en la historia latinoamericana desde Sarmiento, resulta

González y el acusado Klaus Haas (674), de uno de los poemas más conocidos de W.B. Yeats, 'The Second Coming' (La segunda venida). Caracterizado por una abundancia de símbolos cristianos, este poema anuncia la proximidad de una 'segunda llegada', la de la 'bestia sanguinaria' del penúltimo verso, que ha sido interpretada por la crítica como el vaticinio de la Segunda Guerra Mundial.

3 De modo harto significativo, el único personaje que recibe iluminaciones en la novela es la vidente Florita Almada, una especie de charlatana de la que abusan los medios de comunicación y que nadie toma en serio. También hace su aparición un personaje llamado 'Epifanio', y se relatan con ironía las hazañas de un Profanador de iglesias, un maníaco que mea y defeca en los altares.

4 En nuestro artículo "Nuevas pautas para el estudio de los imaginarios (post)apocalípticos en la literatura hispanoamericana” (De Vivanco, Fabry \& Logie, en prensa), hemos postulado el surgimiento de una constelación postapocalíptica en la literatura hispanoamericana postdictatorial y hemos definido sus principales características.

\footnotetext{
Revista Iberoamericana, Vol. LXXX, Núm. 247, Abril-Junio 2014, 611-630 ISSN 0034-9631 (Impreso) ISSN 2154-4794 (Electrónico)
} 
transgredida. Ambas categorías muestran una permeabilidad constante: el espacio urbano ya no representa el polo civilizado de la relación, sino su opuesto. El crecimiento de la megalópolis introdujo la barbarie en el propio contexto urbano: la escalofriante Santa Teresa se plasma como lugar donde ha irrumpido el infierno sobre el posible paraíso. El postapocalipsis se encarna aquí en las dos vertientes señaladas por James Berger: es una urbe distópica (una necrópolis) enterrada en el desierto de Sonora (con sus tierras baldías y sus enormes basurales) (6). Se acabó la era de los simulacros: en palabras de Slavoj Žižek, hemos sido arrojados “al desierto de lo real”, un real puro y duro, en el que la obra de Bolaño está firmemente arraigada.

$\mathrm{Al}$ mismo tiempo, 2666 pone de manifiesto con mucho vigor el agotamiento del poder revelador del final en una época que ya no conoce zonas no contaminadas por el poder y la violencia. Bolaño ha renunciado a la idea de un cataclismo definitivo que pudiera tener dimensiones regeneradoras. Si bien su narrador comparte con el apocaliptista bíblico la necesidad de interpretar y de atribuir una significación a nuestra experiencia de la historia, suprime la luminosa visión del cumplimiento de la salvación común para asumir la contingencia distópica de vivir sin perspectiva redentora. Al negar al acto narrativo una dimensión teleológica, hace evidente la crisis ontológica que nos toca vivir y el escándalo que la ha provocado. Este escándalo se puede resumir con las palabras del filósofo argentino Eduardo Grüner: "Difícilmente haya habido una etapa anterior de la historia en la que tantas y tan poderosas promesas despertadas auténticamente por un estadio de desarrollo económico, social, político y cultural de la humanidad, hayan quedado frustradas hasta la desesperación” (29).

Desde el punto de vista temático, Bolaño reformula aquí las premisas de la literatura hispanoamericana: alejándose de cualquier interpretación mítica dela realidad, ${ }^{5}$ demuestra que sólo una articulación entre ficción y violencia sistémica se ajusta a la mutación del poder que ha tenido lugar en el mundo. ${ }^{6}$ El nuevo ropaje que ha tomado el poder es el de un aparato descentrado de dominio que progresivamente ha ido incoporando la totalidad del globo terráqueo dentro de sus fronteras. En dicha constelación posthegemónica ya no hay interpretación ideológica "clásica" que valga, dado que ya no existe "afuera". De allí que la representación más adecuada del mundo contemporáneo aparezca, según Bolaño, como una pesadilla caracterizada por la violencia y la guerra permanente, verdaderas sinécdoques de la historia contemporánea. Este "imperio" de nuevo cuño (Hardt \& Negri) maneja identidades híbridas, jerarquías flexibles e intercambios plurales a través de redes adaptables de mando y hace que "la violencia social-simbólica en su

5 El rechazo de los estereotipos mitificadores se desprende de frases como ésta: "Estoy harta de los mexicanos que hablan y se comportan como si todo esto fuera Pedro Páramo, dije” (780-781).

6 Es la tesis que defienden tanto Ángeles Donoso Macaya (2009) que reflexiona 'acerca del modo en el que la violencia opera en la novela y trama la ficción' (126, énfasis en el original) como Sergio VillalobosRuminott (2009), desde puntos de vista variados.

ISSN 0034-9631 (Impreso) 
grado más puro apare[zca] como su opuesto, como la espontaneidad del medio en que vivimos o del aire que respiramos” (Žižek 51).

Frente a estas modalidades adoptadas por las nuevas estrategias de dominio, las corrientes postmodernas también se han quedado cortas al condenar en bloque el pensamiento de la modernidad. Grüner ha señalado agudamente el ‘doble vínculo’ que vehiculan esas teorías postmodernas. Reconoce que el problema es complejo porque las dos cosas son ciertas: "el proceso unitario de globalización crea efectivamente fenómenos de fragmentación y dispersión cultural, y ese 'multiculturalismo híbrido' se articula como 'resistencia' a la lógica subyacente de homogeneización unitaria [...]” (387), pero funciona asimismo a modo de celebración de la 'hibridez', entendida como complicidad con el sistema imperial. Ante esta situación, al escritor sólo le queda la opción benjaminiana de reescribir la historia de los vencidos a partir de sus ruinas.

En 2666, las alusiones a los motivos del apocalipsis proliferan sobre todo en los sueños inquietantes que atormentan a los personajes cuando residen en la babilónica ciudad de Santa Teresa, espacio central de la novela situado en el desierto de Sonora. Esta presencia de lo onírico es constante en cada una de las cinco partes, y se narra con una plasticidad poética que hace especial hincapié en la inminencia de la amenaza del fin del mundo. Los protagonistas oyen voces que les inspiran miedo, escuchan ráfagas de viento que provienen de la inmensidad del desierto y pasos de un animal ("la Bestia") que se acerca, vislumbran rostros y bultos, destellos todos del siniestro futuro que le espera a la humanidad y al que sólo se puede tener acceso a través de dimensiones irracionales de la existencia. Despiertan sudando de pesadillas apocalípticas como la que sufre en su habitación de hotel el crítico español Espinoza, en la primera sección: ${ }^{7}$

Espinoza soñó con el cuadro del desierto. En el sueño Espinoza se erguía hasta quedar sentado en la cama y desde allí, como si viera la tele en una pantalla de más de un metro y medio por un metro y medio, podía contemplar el desierto estático y luminoso, de un amarillo solar que hacía daño en los ojos, y a las figuras montadas a caballo, cuyos movimientos, los de los jinetes y los de los caballos, eran apenas perceptibles, como si habitaran en un mundo diferente del nuestro, en donde la velocidad era distinta, una velocidad que para Espinoza era lentitud, aunque él sabía que gracias a esa lentitud, quienquiera que fuera el observador del cuadro no se volvía loco. Y luego estaban las voces. Espinoza las escuchó. Voces apenas audibles, al principio sólo fonemas, cortos gemidos lanzados como meteoritos sobre el desierto y sobre el espacio armado de la habitación del hotel y del sueño. Algunas palabras sueltas sí fue capaz de reconocerlas. Rapidez, premura, velocidad, ligereza. Las palabras se abrían paso a través del aire enrarecido del cuadro como raíces víricas en medio de carne muerta. Nuestra cultura,

7 Todas las citas de 2666 en el presente artículo irán entre paréntesis y remiten a la primera edición de 2004.

Revista Iberoamericana, Vol. LXXX, Núm. 247, Abril-Junio 2014,
ISSN 211-630


decía una voz. Nuestra libertad. La palabra libertad le sonaba a Espinoza como un latigazo en un aula vacía. (153-154)

El narrador omnisciente de 2666 también recurre al registro visionario a la hora de evocar la monstruosa realidad a la que se ven abocados los personajes. Los crímenes cometidos en el infierno de Santa Teresa operan como síntoma de unas plagas cósmicas de alcance planetario. Al constituir el epicentro en el que se encierran las claves de la barbarie occidental, el corazón de la Bestia, Santa Teresa, cuyo cielo al atardecer “parecía una flor carnívora” (172), resulta imposible de describir mediante calificativos concretos: puesto que en sus entrañas se esconde el pavoroso secreto del mundo, la ciudad sólo permite ser denominada en términos metafóricos de “cráter” y de “abismo”, o viéndose asociada con la insistente imagen de las bandadas de zopilotes que acompañan la aparición de los cadáveres que brotan en el desierto.

Una de las paradojas más interesantes de 2666 estriba en que, por más que el narrador omnisciente se empeñe en pintar el horror valiéndose de procedimientos muy divergentes, nunca logra representarlo de modo satisfactorio porque es estrictamente inefable. ${ }^{9}$ Dicha irrepresentabilidad se condensa en el grito que emite el judicial Juan de Dios Martínez después de haber dado con el cadáver de una de las muchachas, Herminia, que ha sido ahorcada de un modo particularmente cruel. El judicial constata que ha cruzado una frontera y que se halla más allá del llanto:

Se cubría la cabeza con las manos y de sus labios escapaba un ulular débil y preciso, como si llorara o pugnara por llorar, pero cuando finalmente retiraba las manos sólo aparecía, iluminada por la pantalla de la tele, su vieja jeta, su vieja piel infecunda y seca, sin el más mínimo rastro de una lágrima. (668)

8 En las páginas 108-109, se evoca una pesadilla muy parecida de Pelletier: en este caso, el personaje ve aparecer un bulto en la playa, y se siente incapaz de levantarse para enterrarlo. Poco después se desata el apocalipsis: "Y entonces observaba un temblor en el mar, como si el agua también sudara, es decir, como si el agua se pusiera a hervir. Un hervor apenas perceptible que se desparramaba en ondas, hasta montarse en las olas que iban a morir a la playa. Y entonces Pelletier sentía que se estaba mareando y un ruido de abejas llegaba del exterior. Y cuando el ruido de abejas cesaba, se instalaba un silencio aún peor en la casa y en las áreas circundantes. [...] Y entonces Pelletier se ponía a llorar y veía que del fondo del mar metalizado emergía lo que quedaba de una estatua. Un trozo de piedra informe, gigantesco, desgastado por el tiempo y por el agua, pero en donde aún se podía ver, con total claridad, una mano, la muñeca, parte del antebrazo. Y esa estatua salía del mar y se elevaba por encima de la playa y era horrorosa y al mismo tiempo muy hermosa”.

9 La prosa (sobre todo la realista) suele fracasar cuando trata de verbalizar la violencia. Según Žižek, contrariamente a la famosa frase de Adorno, no es la poesía lo que es imposible después de Auschwitz, sino más bien la prosa, ya que "la poesía trata siempre, por definición, 'acerca’ de algo que no puede ser nombrado de forma directa, sólo aludido'. Incluso cabe decir que la música acierta donde las palabras fallan: un ejemplo sería la música de Schönberg que 'articula las ansiedades y pesadillas de Auschwitz antes de la existencia de este campo como tal” (13-14).

Revista Iberoamericana, Vol. LXXX, Núm. 247, Abril-Junio 2014, 611-630 ISSN 0034-9631 (Impreso) ISSN 2154-4794 (Electrónico) 
2. UNA URDIMBRE APARENTEMENTE DIGRESIVA

Las cinco secciones de las que se compone 2666 son, en rigor, obras simultáneas, piezas movidas con maestría por un narrador omnisciente: cada una tiene algo que ver con la ciudad de Santa Teresa y con la figura del escritor fantasma, Benno Von Archimboldi, los dos principales hilos conductores de los que salen múltiples ramificaciones narrativas, proliferaciones de historias que se entrelazan a pesar de una urdimbre a primera vista digresiva. Dicho esto, la novela no tiene clausura ya que sus partes no concluyen, sino que se suspenden.

La parte más literaria es la primera, "la parte de los críticos”, que produce literatura sobre una obra narrativa apócrifa, la del enigmático escritor alemán Benno von Archimboldi. Es la historia (a veces hilarante) ${ }^{10}$ de cuatro críticos académicos europeos de fines de los noventa del siglo xx, tres hombres y una mujer -Espinoza, Pelletier, Morini y Norton, cuya obsesión por los escritos del novelista alemán los lleva a encontrarse en sucesivos congresos y que terminan por atraerse hasta conformar un ménage à trois (y luego à quatre) sentimental. En busca de su venerado escritor, los cuatro críticos emprenden vanamente y en plan casi detectivesco un viaje a Santa Teresa, donde se había visto a Archimboldi. Funcionan como símbolo de la parodia de la cultura europea letrada. No descubren al escritor desaparecido, fracasan en el Nuevo Mundo, cuyos códigos ignoran, pero sus pesquisas los conducen hacia un profesor chileno exiliado llamado Amalfitano, un hombre melancólico y defraudado por el mundo.

En la segunda parte, "la parte de Amalfitano", se evoca la investigación sobre las relaciones entre literatura vanguardista y filosofía del profesor Amalfitano, que había traducido al escritor alemán durante su destierro en Buenos Aires. Después de que le hubiera abandonado su mujer Lola, que quedó prendada de un poeta barcelonés, Amalfitano vive con su hija Rosa de 17 años en Santa Teresa donde ha aceptado un puesto de profesor universitario. El ambiente sórdido y ominoso de este páramo cultural hará mella en su salud mental, pues teme por la integridad física de su hija. Amalfitano se aferra al ejemplar del Testamento geométrico de un autor gallego que ha colgado en la cuerda para la ropa del patio de su casa, reproduciendo así un ready made. Opina que esta imagen es más fija y más razonable "que todo lo que había visto en el extrarradio de Santa Teresa y en la misma ciudad, imágenes sin asidero, imágenes que contenían en sí toda la orfandad del mundo, fragmentos, fragmentos” (265).

Con la tercera parte, "la parte de Fate”, Bolaño rinde homenaje a la decisiva influencia de la cultura estadounidense en su formación. Esta sección se focaliza en el viaje del periodista negro Quincy Williams (Óscar Fate), ideológicamente cercano a los Panteras

${ }^{10}$ Presenta a la obra de un autor como el campo de batalla donde los críticos contrapuestos buscan imponer su lectura.

ISSN 0034-9631 (Impreso) 
Negras, quien, tras la muerte de su madre, acaba trabajando en el mundo del deporte: debe viajar a Santa Teresa para hacer un reportaje sobre un combate de boxeo. Aquí va adquiriendo ya auge el tema de la desaparición de las muchachas en la zona de Santa Teresa, tema anticipado con breves alusiones en los capítulos anteriores. Durante su visita a Santa Teresa, Fate se entera de la espantosa realidad de los feminicidios ya anunciada por una temática generalizada de la desaparición y del anonimato (Archimboldi), de la violencia y de la explotación del cuerpo femenino, y es testigo de escenas brutales en una discoteca, sin duda auspiciadas por el crimen organizado. Fate terminará visitando la cárcel para entrevistar a uno de los inculpados. Respecto de los crímenes, en esta parte se lee: 'Nadie presta atención a estos asesinatos, pero en ellos se esconde el secreto del mundo’ (439).

La cuarta parte de la novela, la espeluznante "parte de los crímenes", constituye su zona central y, al mismo tiempo, su agujero negro que condensa a la derrota de toda ley y de toda civilización. Sus páginas son un rosario de depravaciones. En Santa Teresa ocurren desde 1993 repetidos asesinatos de mujeres cuyos cadáveres, restos o huesos aparecen en zonas urbanas céntricas, limítrofes o marginales, en basureros y parques industriales de las numerosas maquiladoras del lugar o en el desierto. Para poder abarcar el insondable abismo del mal, Bolaño, por boca de su narrador omnisciente, detalla con la minuciosidad de un informe forense y uno a uno los 106 asesinatos impunes de mujeres jóvenes, lo que hace que surja en el lector un abrumador efecto acumulativo. Al mismo tiempo, describe pormenorizadamente las ineficaces investigaciones llevadas a cabo por las policías urbana y judicial, estatal y federal. Finalmente, se acusa a Klaus Haas, alemán nacionalizado estadounidense, de los crímenes en serie, sin que parezca que haya muchas evidencias contra él, ya que después de su detención continúan los crímenes. Haas adopta una actitud cínica y se siente un chivo expiatorio, aunque hay indicios en el texto de su culpabilidad, que nunca se aclara del todo, por lo que esta cuestión constituye uno de los múltiples vacíos deliberados del texto. El estrecho vínculo entre las categorías de víctima y verdugo no se debe, como tendremos ocasión de precisar, a la casualidad, sino a una estrategia consciente del autor.

La quinta parte, la "parte de Archimboldi" nos lleva a escenarios bien distintos y explora al personaje enigma de la novela. Trata la infancia, la adolescencia y las aventuras bélicas del escritor alemán, cuyo verdadero nombre era Hans Reiter, y que participará más adelante como soldado en la Segunda Guerra Mundial. Simultáneamente, se relata el nacimiento de su vocación literaria, surgida al encontrar el manuscrito de un muchacho judío ucraniano, Boris Ansky. Al final de la novela, la hermana de Hans Reiter, Lotte, casada con un tal Werner Haas, recibe un telegrama de Santa Teresa en el que se le comunica que su hijo Klaus está preso allí, acusado de una serie de asesinatos cometidos contra diversas mujeres. Archimboldi, cuya vida se resume como una dolorosa y sangrienta versión de la historia del siglo xx, hace el viaje hasta Santa Teresa para

\footnotetext{
Revista Iberoamericana, Vol. LXXX, Núm. 247, Abril-Junio 2014, 611-630 ISSN 0034-9631 (Impreso) IISN 2154-4794 (Electrónico)
} 
ayudar a quien resulta ser su sobrino. De este modo, Bolaño ata ciertos cabos y enlaza las historias fuertemente fragmentadas, confiriéndoles valores simbólicos. Hay que recalcar que tampoco puede considerarse un dato fortuito el lazo de sangre que se establece en las últimas páginas de la novela entre el novelista Archimboldi y el presunto homicida Haas. Mediante un manejo táctico de elipsis y prolepsis narrativas, la novela ha ido construyendo una identificación creciente entre el enigmático "gigante” (alusión a la estatura excepcional de Archimboldi) en quien Klaus ha depositado todas sus esperanzas y su tío, el escritor de culto. De la misma manera, se sugiere un vínculo entre el famoso escritor y la ciudad maldita, sospecha nunca elucidada que se extiende como una sombra sobre la figura de Archimboldi. En su excelente análisis de 2666, Peter Elmore lo formula así: "En esta intemperie moral y existencial, una rara solidaridad conecta a la persona del novelista con la del asesino, trazando así una analogía entre el corpus narrativo y los cuerpos del delito” (261). Cabe mencionar, por último, que el reencuentro entre tío y sobrino es asimismo atribuible a un acto de lectura: Lotte Reiter se reconoce en un libro de su hermano que cae en sus manos mientras está esperando en un aeropuerto, lo que le permite restablecer el contacto.

El abanico de vileza humana, que Bolaño despliega en 2666 y cuyo eje principal son los crímenes de Ciudad Juárez/Santa Teresa, abarca las formas más terribles de la crueldad. La discriminación de negros y mexicanos, los campos de exterminio nazis o la tiranía soviética culminan, desde el punto de vista textual, en la evocación de la cadena de asesinatos de mujeres en la frontera estadounidense, episodio que por sí sólo ocupa 350 páginas de hallazgos de cadáveres en las que Bolaño intenta desbordar a su lector, hartarlo con su estilo forense. En estas páginas interminables se expone la "nuda vida” (Agamben) como una coordenada decisiva en la cartografía imaginaria de nuestra época, en la que la dignidad humana parece haberse reducido a puros cuerpos sin nombre. Santa Teresa, dice Bolaño, como Afganistán o poco antes Chechenia, debe ser considerada como condensado de lo que nos espera en el siglo xxI -siglo que empezó, como dice Hobsbawm, en 1989, con la caída del muro de Berlín.

\section{LA HERMENÉUTICA EN CRISIS}

La línea temática que predomina en 2666, como también era el caso de Los detectives salvajes, es la de la búsqueda frustrada, que plantea una serie de problemáticas candentes en términos equivocados: los personajes no encuentran lo que buscan, pero en cambio encuentran lo que no buscan (los cuerpos de mujeres, en un movimiento de "retorno de lo reprimido”), como si se cumpliera una paradoja inevitable de no intencionalidad, de aparición y desaparición inoportunas. Las mayores incógnitas del libro se corresponden con dos casos de autoría: se siguen desconociendo hasta el final la personalidad del escritor Benno von Archimboldi y la del asesino en serie responsable de las muertes de más de un centenar de mujeres.

\footnotetext{
Revista Iberoamericana, Vol. LXXX, Núm. 247, Abril-Junio 2014,
ISSN 0034-9631 (Impreso)
} 
Planteada en un nivel metaficcional, esta paradoja cobra la forma de una reflexión en torno a la hermenéutica. Así, los críticos europeos de la primera parte no dan con el paradero de Archimboldi y tampoco consiguen eliminar las ambigüedades de su obra; deberán conformarse con la impenetrabilidad de la escritura, de la que no se nos revela nada en la novela ("Archimboldi siempre estaba lejos, en parte porque su obra, a medida que uno se internaba en ella, devoraba a sus exploradores” [47]). Y es que los códigos de su labor académica que los investigadores creían todopoderosos, con su retórica muchas veces vacía y sus rituales de congresos, actas y polémicas, tampoco los ayudan a descifrar mejor el mundo que los rodea: no les sirve de nada cuando el asunto de los feminicidios irrumpe de manera casual en sus vidas. Más allá de los dardos dirigidos contra la Academia, ${ }^{11}$ Bolaño ha querido poner al desnudo una crisis más honda y expresar el agotamiento de la articulación moderna entre espacio público y lectura en el sentido ilustrado de educación y ejemplificación moral (Villalobos-Ruminott 194).

A los pocos días de la llegada de los críticos a Santa Teresa, la realidad "pareció rajarse como una escenografía de papel, y al caer dejó ver lo que había detrás: un paisaje humeante, como si alguien, tal vez un ángel, estuviera haciendo cientos de barbacoas para una multitud de seres invisibles” (179). Desarmados, observan que ha aumentado su ceguera y que de pronto ya ni entienden los libros de Archimboldi, estudiados con tanto ahínco (172). Sólo cuando empiezan a leer con nuevos ojos, entregándose a las obras, se crea cierto margen para las experiencias epifánicas y para el encuentro consigo mismos. Entonces son capaces de tomar decisiones importantes que afectan a su vida íntima, por ejemplo la de Liz Norton de romper relaciones con sus dos colegas, Espinoza y Pelletier, y de instalarse en el piso del tetrapléjico Piero Morini.

En general, se roza lo oculto pero no se logra desvelarlo porque sólo con medios artísticos es posible acercarse a su expresión sin que el misterio deje de persistir. Al contrario: cuanto más se lo denomina, más se resiste a ser formulado y conocido. El editor de Archimboldi, el incondicional señor Bubis, judeoalemán de Hamburgo, reconoce su impotencia a la hora de explicar por qué el manuscrito de Herencia le resulta tan satisfactorio, pero intuye que la literatura de su autor puede ser una manera de resistir al poder. No es que cumpla sus expectativas sobre el "buen quehacer literario" ni sobre la "capacidad de fabulación" o la de "inyectar sangre nueva en la aterida lengua alemana" (1049): “¿Qué era, entonces? Bubis no lo sabía aunque lo presentía, y el no saberlo no le producía el más mínimo problema, entre otras cosas porque tal vez los problemas empezaban al saberlo [...]” (1049-1050). Dicho de otro modo, algún potencial, por inasible que sea, parece quedar en pie en 2666: el arte puede seguir produciendo conciencia y perspicacia.

${ }^{11}$ Bolaño se burla de diferentes tipos de crítica académica: uno de sus blancos es la práctica crítica "ultraconcreta" que no aporta ideas, sino únicamente datos, como en una 'arquelogía de la fotocopiadora' (78-79).

Revista Iberoamericana, Vol. LXXX, Núm. 247, Abril-Junio 2014, $611-630$
ISSN 0034-9631 (Impreso) 
Sin embargo, esta capacidad transfiguradora que puede emanar de la creación sólo aflora bajo condiciones muy estrictas, dado que presupone un ejercicio de equilibrio sumamente precario en el que a cada paso se corre el riesgo de cruzar la frontera de la violencia. Semejante praxis implica redes dionisíacas, como el desenfreno de la imaginación y la transgresión constante de las normas establecidas por la sociedad, experiencias que pueden conducir tanto a la liberación como a la (auto)destrucción. Lo que revela sobre todo es el hecho de que el horror no es una desviación de lo real, sino una de sus múltiples pero intrínsecas caras, una de sus facetas íntimas. Surgen entonces las preguntas acuciantes de si a principios de este siglo xxı, que se atisba infame, aún es posible reconciliar la búsqueda de las experiencias al límite individuales con las apuestas éticas, y de cómo se plasma la necesidad urgente de nuevos proyectos de futuro que recuperen sentidos colectivos.

De la inmensa mayoría de discursos y peripecias que se suceden en la novela habría que inferir que estamos en un callejón sin salida, y que 2666 clausura el siglo xx expresando dos naufragios. El primero atañe a la militancia convencional de la izquierda, en la que todavía creía la generación del propio Bolaño, representada aquí por el personaje de Amalfitano, que encarna las derrotas y pérdidas del proyecto revolucionario. ${ }^{12} \mathrm{El}$ segundo naufragio es el que ha afectado a cierta vieja concepción humanista del arte. En la actualidad, se asume que la literatura ya raramente incomoda o ilumina. Atrás ha quedado la sacralización de la figura del artista que marcó el período modernista de nuestra cultura, por lo que el arte ha perdido su poder emancipador: ha dejado de ser una fuerza civilizadora para ponerse al servicio de regímenes totalitarios, o para disolverse en el triunfo banal de la industria cultural. Como es sabido, las tradiciones artísticas vanguardistas del siglo xx han predicado las actitudes de la rebeldía y de la transgresión, reivindicando una mejor integración del arte en la vida cotidiana, pero al quebrar todas las leyes y restricciones, la petición de libertad absoluta ha ido acompañada irremediablemente de la formulación de nuevos autoritarismos y prácticas que a su vez han entrañado actos abyectos.

En 2666, esta tenue línea que separa la normalidad del sadismo o de la locura, al héroe del monstruo, se pisa con mucha frecuencia. No es el privilegio exclusivo de la "Parte de los crímenes", sino que toda la novela está salpicada de escenas violentas. Hasta los aparentemente pacíficos expertos académicos de la primera sección cometen un acto de violencia extrema cuando, inexplicablemente, golpean de modo brutal a un

${ }_{12}$ Si se retraza la evolución intratextual de la fecha 2666, los constantes desplazamientos textuales de los que es objeto, se descubre que, en obras diferentes, designa las dos caras opuestas de la medalla: en Amuleto, remite a un cementerio del futuro, mientras que en Los detectives salvajes es la fecha hacia la que se proyecta la Revolución.

Revista Iberoamericana, Vol. LXXX, Núm. 247, Abril-Junio 2014,
ISSN 0034-9631 (Impreso) 
taxista paquistaní en Londres (101 y ss), al sentirse ofendidos por su discurso sobre la decencia moral. Curiosamente, lo que esa paliza les depara es una sensación de gran satisfacción y excitación (la definen como “una mezcla de sueño y deseo sexual” [105]), y no de culpabilidad.

Otro ejemplo llamativo se encuentra en la quinta parte. Se produce durante una velada en el castillo del Conde Drácula en la región de los Cárpatos, adonde Archimboldi ha ido a parar en sus peripecias bélicas. En dicho castillo, se encuentran varios jerarcas de las SS con algunos militares rumanos, comandados por el carismático general Eugenio Entrescu, aliado rumano de Hitler. En la cena, Entrescu avanza una serie de teorías poco ortodoxas en torno a la supremacía de la vida sobre el arte (“dijo que cualquier pared abandonada o cualquier pared bombardeada era más interesante que la más famosa obra cubista” [854]), además de que destaca la inextricabilidad de civilización y barbarie (851; 856-857). Convencido de su propia superioridad, Entrescu proclama estar seguro de ejercer un dominio absoluto sobre sus soldados, y hace alarde de saber leer su pensamiento (855). Su legendario machismo se confirma cuando, horas más tarde, Archimboldi logra penetrar en el edificio y espiar desde un pasillo secreto al general mientras practica el amor de forma desenfrenada y espectacular con su amante, la voluptuosa baronesa Von Zumpe (863-866). El frenesí inagotable de la orgía sexual se invierte, sin embargo, en la increíble escena posterior del sacrificio del tirano, la contrapartida exacta de la desmesura vitalista. Entrescu termina crucificado a los pies del castillo del Vampiro por sus propias tropas, unos harapientos peligrosos en desbandada ante el contraataque soviético que desean desertar, acto que Archimboldi presencia y comenta con lujo de detalles (930-932). Bolaño ha reescrito el pasaje bíblico de la muerte en el Gólgota en clave innegablemente paródica, ya que para Entrescu ninguna resurrección será posible. Resuenan en estas páginas grotescas ecos del "Evangelio según Marcos” de Jorge Luis Borges, al tiempo que se movilizan los estereotipos más característicos de la novela gótica (que culminó en la novela Drácula de Bram Stoker) y de la "novela del dictador" hispanoamericana (por los atributos hiperbólicos -el tamaño descomunal de su verga- y la sed insaciable de poder que se atribuyen a Entrescu). La explotación condensada de diferentes capas intertextuales pone de manifiesto otro rasgo de la escritura de Bolaño: la desrealización de la apariencia del mundo por la constante contaminación por la ficción.

Habiéndose despedido de la dimensión transcendente, metafísica de la escritura, con sus fuertes resonancias utópicas, Bolaño ha explorado con predilección esas zonas fronterizas, esa complicidad perversa entre artistas y poder, razón por la cual muchos de sus personajes principales son artistas, que participan tanto de la creación como del terror policial. El ejemplo más representativo de esta yuxtaposición constante de la ficción criminal y la pesquisa artística es Carlos Wieder, protagonista de Estrella distante, poeta futurista y artista oficial del régimen pinochetista que reivindica sus crímenes, la

\footnotetext{
Revista Iberoamericana, Vol. LXXX, Núm. 247, Abril-Junio 2014, 611-630 ISSN 0034-9631 (Impreso) ISSN 2154-4794 (Electrónico)
} 
tortura de una serie de mujeres, como actos estéticos que se sitúan en la prolongación vanguardista. Valiéndose de los análisis de Poggioli, Huyssen y Hutcheon, Jeremías Gamboa Cárdenas (2008) percibe "un acercamiento progresivamente más estrecho" entre dos formas de aparición supuestamente contradictorias de la praxis vanguardista: la del artista dandy frente al bohemio (216-217).

A esta consustancial solidaridad entre cultura y barbarie, a esta alternancia bipolar, también obedecen, aunque en mucho menor medida, varias figuras clave de 2666, como el propio Archimboldi, que también mata deliberadamente a un hombre (Sammer, véase infra) y se dispone a vengar a su sobrino delincuente Klaus Haas. Aparentemente, no puede ser de otra manera en una época en la que hacer el mal se ha hecho indisociable de la lógica de la violencia planetaria de la historia: los acontecimientos no pueden ser considerados objetos exteriores al observador; éste se halla plenamente inmerso en su contexto y se da una "co-belonging between literature and horror" (VillalobosRuminott, 194), perteneciendo ambos campos al mismo ámbito. La complicidad ha dejado de ser voluntaria para volverse estructural, y ha desacreditado formas más directas de denuncia como el ya clásico "testimonio" latinoamericano en el que las víctimas tomaban la palabra. ${ }^{13}$ En base a este argumento, Villalobos-Ruminott $(194,200)$ considera a Bolaño un escritor globalizado que se sale de los marcos latinoamericanos de la narrativa postdictatorial hispanoamericana: para ser comprendida cabalmente, su obra requiere un posicionamiento dentro de la literatura mundial entendida en el sentido de "historia del mundo a través de la destrucción global", de la que forman parte, entre otros, Sebald o Pynchon.

En otras palabras, Bolaño plantea poderosamente la cuestión del potencial de la literatura como praxis en nuestra época. Opina que la fuerza del escritor reside en la herramienta más específica que tiene a su disposición: la singularidad irreductible de su forma interior, su descripción artística, entendida en su acepción amplia de organización de la trama, perspectiva narrativa, estilo y locus desde donde se habla. En el arte -el que realmente importa- coexisten lo uno y lo múltiple, por lo que sabe dar cuenta de los desgarramientos simbólicos de Occidente. La situación actual exige nuevos modos de abordar lo "real", que ha adquirido dimensiones inauditas después de Auschwitz, las dictaduras del Cono Sur y la violencia arbitraria de Ciudad Juárez. Esos modos de abordar "lo real” no sólo afectan al plano temático del enunciado, sino y sobre todo al de la enunciación. Para que la voz del escritor recupere cierta legitimidad, debe escribir una obra cuyo compromiso estético coincida con su compromiso ético, por lo

13 Žižek (12-13) pone el dedo en la llaga cuando compara un acercamiento desapasionado a la tipología de la violencia (verdadero y factual, pero poco veraz) con las descripciones de los traumas en el testimonio (donde lo que otorga veracidad es lo que contamina el modo de informar, dando lugar a la llamada 'no fiabilidad' de estas descripciones verbales).

Revista Iberoamericana, Vol. LXXX, Núm. 247, Abril-Junio 2014,
ISSN 0034-9631 (Impreso) 
que los procesos de ficcionalización no deben ser entendidos como un mero intento de estetización. Es sobre todo la variación de estrategias narrativas y modos de contar desplegados lo que permite que 2666 alcance este objetivo.

\section{MODALIDADES DE REPRESENTACIÓN DEL HORROR}

De la tematización del horror y de su problemática expresión se hace cargo, en la cuarta parte, la construcción de una voz narrativa neutra, carente de afecto, que parece registrar mecánicamente y en focalización cero las circunstancias en que se hallan las fallecidas y que difiere considerablemente del modo narrativo que se da en las otras partes, ordenadas en torno a personajes determinados. El impacto de esta instancia impropiamente distante resulta reforzado por la acumulación de información pormenorizada que satura al lector sin que, paradójicamente, esta sobredosis de hechos y datos contribuya a informarlo mejor. El efecto de la combinación es contraproducente y subvierte las reglas del subgénero de la crónica negra, porque no hay desenlace alguno: la voz que lo anota todo parece encaminarse hacia la revelación de una verdad que se sustrae permanentemente, lo cual provoca un efecto de malestar y de extrañeza en el lector. Como no se le comunica nada de lo esencial -la forma de los crímenes, sus autores y sus móviles, triunfa finalmente un silencio opaco y perverso. Sólo se barajan hipótesis que se contradicen entre sí, se avanzan teorías truncas sobre los crímenes como la de las "snuff movies", que inmediatamente quedan invalidadas por casos de violencia que se insertan en la misma serie, aunque no responden al mismo patrón. Y a pesar del rigor descriptivo que se asocia con el registro forense, surge la impresión de que se introducen elementos incompatibles con el tono fáctico, como los modalizadores de duda o de posibilidad.

A fin de cuentas, se nos presenta un abanico difuso de modalidades del delito que aumenta la arbitrariedad y nos deja creer que el comportamiento delincuente es un comportamiento generalizado que afecta a muchos grupos de la población y es fruto de una mentalidad misógina y gregaria que sucumbe fácilmente al autoritarismo. Tal criminalidad llega a implicar a toda la sociedad mexicana: los asesinatos de estas mujeres violadas, estranguladas o golpeadas sólo forman su triste colmo, la intensificación de unos desmanes impunes, igualmente presentes en los abusos policiales, en la violencia de las cárceles y en las condiciones de trabajo de las maquiladoras con sus sueldos miserables, sus horarios inhumanos y sus despidos inapelables. Por todo aquello, el cataclismo de Santa Teresa no se nos pinta ni como exclusivamente mexicano, ni como excepcional; antes bien, funciona como metáfora del paisaje horroroso que caracteriza a nuestro universo contemporáneo y de la violencia máxima que lo impregna: una violencia tan extrema que ni siquiera permite que se la transgreda. O sea que Bolaño opta precisamente por un narrador tan objetivo y supuestamente mimético como el perito médico para

\footnotetext{
Revista Iberoamericana, Vol. LXXX, Núm. 247, Abril-Junio 2014, 611-630 ISSN 0034-9631 (Impreso) ISSN 2154-4794 (Electrónico)
} 
indicar los límites de la descripción literaria y la imposibilidad hermenéutica encarnada por asesinatos tan terribles que resisten cualquier representación. Son estrictamente incontables e ilegibles, por lo que su lectura resulta intolerable. ${ }^{14}$

La escena de barbarie sobre el feminicidio que abarca casi toda la cuarta parte es la más extensa y la más impresionante de la novela, pero dista mucho de ser la única. En otra sumamente emblemática, la del genocidio judío evocado en "La parte de Archimboldi”, se mantiene intacta la impotencia para alcanzar el corazón del abismo a pesar de que se vale de una técnica narrativa radicalmente distinta. El horror del holocausto sólo está presente indirectamente, por persona interpuesta, mediante la historia de Leo Sammer (episodio estremecedor que se narra en apenas 20 páginas, 938-960). Junto con este Sammer (o Zeller, su nombre falso), Archimboldi (que en aquel entonces todavía se llamaba Hans Reiter) aguarda, al final de la Segunda Guerra Mundial, en un campo de concentración americano el interrogatorio por el que pasan todos los prisioneros alemanes. Un día, Zeller/Sammer, en régimen de narrador personal, confiesa a su compañero que fue subdirector de un organismo encargado de suministrar trabajadores al Reich. Su peor experiencia se produjo cuando a ese pueblo llegó desviado un tren con quinientos judíos que habían embarcado en Grecia. Cuando Sammer pide instrucciones, en Berlín le responden que el tren iba con destino a Auschwitz, que ya no tienen cómo trasladar a los judíos allí y que se encargue él como pueda. Sammer termina por cumplir órdenes y se deshace, efectivamente, de ellos: los judíos son fusilados y enterrados en una hondonada que funciona como fosa común, a quince kilómetros de la ciudad; sus cuerpos, sin embargo, reaparecen sin cesar y resulta imposible borrar sus rastros (952). Después de su confesión, Archimboldi matará al exterminador de judíos que no es quien pretendía ser. En una guerra, siempre se es a un tiempo victimario y víctima.

Para narrar y minimizar el horror del exterminio de los judíos, el colaboracionista Sammer copia los procedimientos del régimen totalitario: la elipsis, el no dicho y el eufemismo ("solucionar el problema”), técnicas que difieren totalmente de la reiteración maniática que domina en la parte anterior, aunque esta última, como hemos visto, también produce un efecto de distanciamiento. Sea por la omisión, sea por un exceso de precisión, las palabras parecen tener que violentarse a la hora de narrar el mal.

Pero hay más. Como ha demostrado con mucha agudeza Ángeles Donoso Macaya, el vínculo entre las dos escenas que tematizan la irrepresentabilidad del mal se ancla de modo estructural en la novela a través del procedimiento de la repetición de elementos distintos: "En 2666, entonces, se organizan y se coordinan diversos hechos originalmente inconexos bajo el motivo de la repetición. La repetición no sólo le otorga un nuevo significado a los crímenes repetidos en serie y deserializados en la ficción tramada por

14 Žižek confirma el efecto paradójico de un análisis frío de la violencia, que de algún modo "reproduce y participa de su horror" (12).

Revista Iberoamericana, Vol. LXXX, Núm. 247, Abril-Junio 2014, $611-630$
ISSN 0034-9631 (Impreso) 
el narrador, sino que a la vez propone una nueva comprensión de la noción misma de repetición: en 2666 se repite lo heterogéneo y no lo similar” (132-133; énfasis en el original). Según este razonamiento, ciertas relaciones, por ejemplo entre el genocidio del pueblo judío en la Alemania nazi y los feminicidios que se perpetran en la frontera entre México y Estados Unidos, sólo pueden mostrarse "dentro del espacio creado por la literatura, dentro del territorio de la ficción” (Donoso Macaya 138). 2666 expone en su plano de enunciación la metodología sistemática de estos crímenes -o sea que hace aparecer un nexo allí donde aparentemente no lo había y hace visibles/decibles estas formas de violencia propias del último siglo: el exterminio, la desaparición, los asesinatos en serie (Donoso Macaya 134-135).

De todo lo anterior se desprende que, pese al reconocimiento del estatuto ambiguo del arte, Bolaño asigna una vocación ética al artista:

Sucede, sin embargo, que dela versátil puesta en escena de sus relaciones y combinaciones no se desprende una ética del Mal; lo que el curso de la novela despliega es, más bien, una inquisición en los límites y el sentido de esa ética, de prestigio contestatario y rebelde, a la luz de las hecatombes totalitarias y de la violencia cotidiana contra las mujeres. (Elmore 271)

\section{TRES CONSTRUCCIONES EN ABISMO}

Reordenar la realidad a partir de procedimientos artísticos es una actividad a la que se dedican varios personajes de 2666. Encontramos en la novela constantes reflexiones sobre la escritura y la pintura que se formulan a través de la evocación de vidas de creadores. La finalidad principal de estos relatos internos (imbricación de una narración dentro de otra) o “composiciones en abismo”, es la de tematizar el proceso de fabricación de la novela que constituye su marco, y de revelar sus principios de funcionamiento más destacados. Poniendo al desnudo diferentes modalidades de representación de la violencia omnipresente, la instancia enunciadora del narrador omnisciente dialoga con ellas y, al hacerlo, nos ofrece un comentario en filigrana sobre sus propias elecciones. Al mostrar las debilidades o puntos fuertes de otras apuestas artísticas, este narrador se posiciona con respecto a ellas.

Dentro de la galería inagotable de perfiles de artistas a veces estrambóticos, tres llaman particularmente la atención por su pertinencia frente a la estrategia narrativa principal del libro, que es la vía indirecta o la oblicuidad. Si bien varios elementos las separan, lo que estas tres respuestas estéticas tienen en común es su índole ambiciosa y corrosiva, y su entrega total al arte.

Aunque sólo aparece como personaje secundario en la primera parte, la figura del pintor londinense Edwin Johns no carece de interés simbólico. Surge por primera vez en las conversaciones entre Liz Norton y Piero Morini, que acabarán por compartir

Revista Iberoamericana, Vol. LXXX, Núm. 247, Abril-Junio 2014, $611-630$
ISSN 0034-9631 (Impreso) 
una fascinación por la radicalidad de sus gestos. Instalado en un barrio postindustrial desfavorecido, Johns busca hacerse cargo de la miseria de este entorno a través de cuadros de grandes dimensiones en tonos grises y "lúgubres trazos salvajes", como si entre el pintor y el barrio "se hubiera producido una simbiosis total” (76). Pero la pieza maestra de la exposición con la que se da a conocer es un autorretrato muy sui géneris en cuyo centro pende, momificada, su mano derecha (76), es decir, la mano con la que pintaba. Fruto de una automutilación extrema, ${ }^{15}$ este cuadro estrella inaugura un nuevo movimiento artístico, el "nuevo decadentismo" o "animalismo” inglés (76). Bolaño introduce aquí una nota crítica, puesto que en lugar de inspirar repulsión o de provocar una toma de conciencia en el público, el autorretrato, hecho en señal de protesta contra la sociedad y contra el arte oficial con sus instituciones dadoras de prestigio, es recuperado por la lógica implacable del mercado: amén de dar lugar a la fundación de una corriente artística, la exposición es un enorme éxito comercial, los precios se disparan (la pieza maestra es adquirida por un árabe que trabaja en la Bolsa), y se pone en marcha el proceso de gentrificación del barrio (77).

Cortarse la mano para exhibirla en un retrato autobiográfico equivale, para el pintor, a infligir a su propio cuerpo la violencia que le rodea, pero también provocará su locura: ${ }^{16}$ poco después será internado en un psiquiátrico en los Alpes suizos, adonde los tres críticos masculinos irán a visitarlo (119). Debido a la minusvalidez de Johns, es particularmente intensa la identificación que se produce entre él y Morini, quien será el primero en enterarse de la muerte del pintor en una caída melodramática. Antes que cualquier representación mimética, el método literal de Johns aparenta ser, a primera vista, el más propicio a la hora de evocar el horror, porque expone en toda su desnudez física el objeto real. Sin embargo, una comparación entre los procedimientos sesgados adoptados por el narrador extradiegético de 2666 y la actuación metonímica de Johns revela el rechazo de esta última que, pese a su apariencia de máxima autenticidad, peca de ingenua, efectista y convencional.

Otras dos figuras dotadas de fuertes dosis de autorreferencialidad son las de Boris Abramovich Ansky y Benno von Archimboldi, los dos escritores inseparables que protagonizan la quinta parte. De hecho, el seudónimo de Hans Reiter, Benno von Archimboldi, germánico y latino a un tiempo, constituye un homenaje a Ansky ya que Guiseppe Arcimboldo se cuenta entre los pintores favoritos de Boris Abramovich.

15 El gesto radical de Johns despierta asociaciones con el caso Van Gogh, o con el uso que Damien Hirst hace de la taxidermia. Teniendo en cuenta la presencia importante en la obra de Bolaño del poeta chileno Raúl Zurita, representante de la posvanguardia chilena opuesta al régimen de Pinochet, tampoco hay que descartar las performances de este último como fuentes de inspiración (automutilación de la cara con un hierro candente).

16 Otro loco digno de mención es el poeta barcelonés del que se enamora perdidamente la mujer de Amalfitano, y cuyo modelo podría ser el poeta español Leopoldo María Panero.

Revista Iberoamericana, Vol. LXXX, Núm. 247, Abril-Junio 2014, $611-630$
ISSN 0034-9631 (Impreso) 
En una casa ucraniana abandonada donde Hans Reiter se recupera de sus heridas de guerra, llega a tener una experiencia iniciática: en un escondite detrás de la chimenea encuentra un cuaderno impregnado de experimentalismo y lleno de ideas disparatadas que impulsa su propia vocación literaria. El cuaderno resulta ser de Ansky, un muchacho judío ruso que a los 15 años decide alistarse en el ejército rojo, pasa tres años viajando por Siberia hasta que llega a Moscú, donde escribe novelas de ciencia ficción firmadas por el inescrupuloso Efraín Ivánov, un escritor mediocre que se adecúa al establishment soviético pero que caerá en desgracia. ${ }^{17} \mathrm{La}$ afinidad de Reiter con Ansky no pasa únicamente por la literatura, sino también por el estatuto compartido de testigo de las destrucciones del siglo xx. Si a Reiter le han tocado los desastres del nazismo y del antisemitismo, Ansky es su hermano siamés, que ha vivido la otra gran experiencia totalitaria, la de las purgas del estalinismo. No en vano obsesiona a Reiter la pesadilla de haber sido el causante de la muerte del escritor judío (922), que finalmente desaparece al unirse a un grupo de guerrilleros que combate a los invasores alemanes.

Como queda dicho, es a través de los papeles de Ansky como Reiter tiene acceso a dos perfiles de artistas: por una parte, a las ideas de Courbet como paradigma del pintor revolucionario, y por otra a la "alegría personificada” (917-918), la levedad del pintor manierista GuiseppeArcimboldo, famoso por sus “cabezas compuestas”, rostros humanos elaborados a partir de frutas, verduras, hojas y animales, y cuyas obras conforman una totalidad que se reorganiza permanentemente.

Inspirándose en el ejemplo de Ansky, Archimboldi se convertirá en un escritor sumamente prolífico pero casi clandestino, una especie de Salinger alemán, que rehúye las apariciones públicas que tanta ilusión le hacen a los Ivánov de este mundo. Surgiendo desde la nada (para su primera novela tiene que alquilar una máquina de escribir), alcanza poco a poco la fama de un autor de culto y su nombre circula como posible candidato al Nobel. ${ }^{18}$ Por su compromiso absoluto con el arte y su radical independencia, puede llegar a ser un testigo excepcional de su época, un antihéroe imperturbable que no se muestra dispuesto a transigir con el sistema.

De los ensayos sobre literatura que ha escrito Bolaño y que se han recogido en el volumen Entre paréntesis, cabe deducir que la concepción del arte que subyace a la obra de Archimboldi es la más cercana a la suya propia, que plantea que la efectividad del arte se restringe a las obras que son capaces de abandonar el realismo y que se construyen como desestabilización de la forma. Aunque menos idealista y más estoico

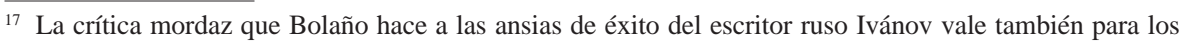
escritores e intelectuales mexicanos que pueblan la 'Parte de los crímenes', caracterizados en su gran mayoría como cortesanos seducidos por las prebendas del Estado.

${ }_{18}$ Algunas de las caracterizaciones de la reputación de Archimboldi son casi literalmente aplicables a la celebración póstuma consensuada de la persona del propio Bolaño; también en este caso cabe hablar de una canonización contracanónica.

Revista Iberoamericana, Vol. LXXX, Núm. 247, Abril-Junio 2014, 611-630
ISSN 0034-9631 (Impreso) 2154-4794 (Electrónico) 
que su habitual álter ego Arturo Belano, supuesto narrador de la novela, ${ }^{19}$ Archimboldi reúne los requisitos fundamentales para ser considerado como una autofiguración del autor: solitario, valiente, irrespetuoso e indomable. ${ }^{20}$

\section{EL POSTMODERNISMO QUE YA FUE}

En la superficie, el abanico de estrategias narrativas puestas en obra por el narrador principal de 2666recuerda la novelística postmoderna, con sumultiplicación de 'pequeñas historias', su pronunciada concienca metanarrativa y su hibridez genérica. Sin embargo, la complejidad de la novela nos lleva a creer que significa un paso adelante respecto a cierta literatura postmoderna lúdica y "light”, en la que la complacencia autoindulgente reemplazaba la voluntad de articular literariamente la resistencia. Lo que hace Bolaño, con su lucidez implacable, es articular todos los "pequeños relatos" con una radiografía de conjunto, al dejar ver que el sistema o el mercado o el "imperio" o como se lo quiera llamar no es un mecanismo benigno que funciona mejor cuando se lo deja trabajar en paz, sino que exige mucha violencia paralela para crear las condiciones para su funcionamiento; el genocidio casi sin precedentes que se oculta detrás de elegantes eufemismos como "neoliberalismo" o "globalización”.

Gamboa Cárdenas sostiene que Bolaño ocupa una posición de distancia crítica con respecto a la novela contemporánea, que define como "la inscripción del programa de la vanguardia bajo una aparente estrategia posmoderna” (231-232). Antes que apropiarse de las estrategias discursivas de la narrativa postmoderna, las desafía en la medida en que se niega a cuestionar la realidad de los eventos políticos y a contemplar el mundo como pura ficcionalización.

O sea que, para retomar nuestras categorías iniciales, la reacción más lógica pero a todas luces insuficiente para demostrar el vacío ontológico actual es renunciar al mito de salvación apocalíptica, ya que toda intención totalizadora está condenada al fracaso. En After the End, Berger ha declarado que, a finales del siglo xx, lo inimaginable y lo inefable no sólo han ocurrido, sino que continúan ocurriendo, por lo que nos encontramos ante una situación histórica inédita. Su tesis es que tenemos que aspirar a plantear la representación de lo irrepresentable; de allí que conciba lo "postapocalíptico" como un síntoma por descifrar, cuya historia traumática subyacente debe ser comprendida, o al menos planteada, a fin de poder otorgarle un sentido. Sólo así estas narraciones dejarán

19 De acuerdo con el epílogo de Ignacio Echevarría, Bolaño puso en sus anotaciones que Belano era el verdadero narrador de 2666 (1125).

20 Asume el credo que Bolaño resume en su ya famoso "Discurso de Caracas”: “¿Entonces qué es una escritura de calidad? Pues lo que siempre ha sido: saber meter la cabeza en lo oscuro, saber saltar al vacío, saber que la literatura básicamente es un oficio peligroso. Correr por el borde del precipicio: a un lado el abismo sin fondo y al otro las caras que uno quiere [...]" (Entre paréntesis 36).

Revista Iberoamericana, Vol. LXXX, Núm. 247, Abril-Junio 2014,
ISSN 0034-9631 (Impreso) 
de ser meras narraciones de ruptura y ruina en las que terminaremos atrapados; en el caso contrario, continuaremos con el proceso de desmantelamiento de la civilización, un statu quo que simplemente no es una opción viable.

En la segunda parte de 2666, Amalfitano pronuncia un alegato a favor de las novelas totales e imperfectas, que abren camino a lo desconocido (289-290), y contra la literatura menor. Prefiere los “combates a muerte” impregnados de derrota a las “clases de esgrima” que no comprometen a mucho, formulando de este modo el propio programa poético de Bolaño. Tales novelas, que tienen "sangre y heridas y fetidez" (289-290) no se sustraen a la violencia, sino que exploran las posibilidades de la escritura después de la catástrofe. Su eje rector consiste en establecer una topografía de la nebulosa del mal y de sus nuevas máscaras, buscar modos de representarla mediante la complejidad estética, a sabiendas de que se trata de una empresa condenada al fracaso. Aunque la obra literaria sólo puede acercar la búsqueda humana del corazón del abismo, no por ello debe renunciar a la tarea, puesto que esto es lo que legitima el arte en el mundo de hoy.

\section{BiBLIOGRAFÍA}

Berger, James. After the End. Representations of post-apocalypse. Minneapolis: U of Minnesota P, 1999.

Bolaño, Roberto. 2666. Barcelona: Anagrama, 2004.

Entre paréntesis. Ensayos, artículos y discursos (1998-2003). Ignacio Echevarría, ed. Barcelona: Anagrama, 2004.

Donoso Macaya, Ángeles. "Estética, política y el posible territorio de la ficción en 2666 de Roberto Bolaño”. Revista Hispánica Moderna LXII/2 (December 2009): 125-142.

Elmore, Peter. “2666: la autoría en el tiempo del límite”. Bolaño salvaje. Edmundo Paz Soldán y Gustavo Faverón Patriau, eds. Barcelona: Candaya, 2008. 259-292.

Fabry Geneviève, Ilse Logie y Pablo Decock, eds. Los imaginarios apocalípticos en la literatura hispanoamericana contemporánea. Bern: Peter Lang 'Hispanic Studies: Culture and Ideas’, 2010.

Gamboa Cárdenas, Jeremías. “¿Dobles o siameses? Vanguardia y postmodernismo en Estrella distante”. Bolaño salvaje. Edmundo Paz Solán y Gustavo Faverón Patriau, eds. Barcelona: Candaya, 2008. 211-236.

Grüner, Eduardo. El fin de las pequeñas historias. De los estudios culturales al retorno (imposible) de lo trágico. Buenos Aires: Paidós, 2002.

Olivier, Florence. "Santa Teresa en 2666 de Roberto Bolaño: ciudad límite, ciudad del crimen impune”. Las ciudades y el fin de siglo XX en América Latina: literaturas, culturas, representaciones. Teresa Orecchia Havas, ed. Bern: Peter Lang, 2007.31-42.

Paz Soldán, Edmundo. "Roberto Bolaño: literatura y apocalipsis”. Bolaño salvaje. Edmundo Paz Solán y Gustavo Faverón Patriau, eds. Barcelona: Candaya, 2008. 11-30.

Revista Iberoamericana, Vol. LXXX, Núm. 247, Abril-Junio 2014, $611-630$
ISSN 0034-9631 (Impreso) 
Slate, Adam. “Sloutching Towards Santa Teresa”. Slate Magazine. 3 nov. 2008. <http:// www.slate.com/id/2203471> 13 oct. 2010.

Villalobos-Ruminott, Santiago. "A Kind of Hell: Roberto Bolaño and the Return of World Literature”. Journal of LatinAmerican Cultural Studies XVIII/2-3(December 2009): 193-205.

Vivanco, Lucero de, Geneviève Fabry y Ilse Logie. "Nuevas pautas para el estudio de los imaginarios (post)apocalípticos en la literatura hispanoamericana”. Nuevos hispanismos interdisciplinarios y trasatlánticos. Tomo II. Julio Ortega, ed. Madrid/ Frankfurt am Main: Iberoamericana/Vervuert, en prensa.

Žižek, Slavoj. Sobre la violencia. Seis reflexiones marginales. BuenosAires: Paidós, 2009.

Revista Iberoamericana, Vol. LXXX, Núm. 247, Abril-Junio 2014,
ISSN 0034-9631 (Impreso) 